\title{
KADAR INTERFERON GAMMA (IFNY) PADA PASIEN TOKSOPLASMOSIS YANG ASIMPTOMATIK
}

\author{
Armaidi Darmawan, Maria Estela Karolina, Hanina \\ Program Studi Kedokteran Fakultas Kedokteran dan IImu Kesehatan Universitas Jambi \\ Email: armaididarmawan@yahoo.co.id
}

\begin{abstract}
Background: Toxoplasma gondii is a species that is able to modulate its host immune system. T.gondii infection causes an increased Th1 response to produce IFNY, TNFa and IL-12 secreted by T. IFNY lymphocytes which are activated and cause increased production of Nitric Oxide (NO) which can cause cell apoptosis and IFNy can destroy T.gondii with several mechanisms. The aim of this study was to determine IFN levels in patients with positive $\lg G$ and asymptomatic lgG toxoplasmosis.

Methods: Case control research with experimental laboratories that use human blood as the object of research. The subjects were initially checked for blood with IgG Rapid Test to determine the positive or negative Toxoplasma infection. IFNy levels are checked by the ELISA method. To analyze the average comparison of IFNy levels using computer software. Test the data normality with Saphiro-wilk and comparison of IFNy levels with Wilcoxon test.
\end{abstract}

Results: IFNy levels in the negative IgG group (4.69) were slightly lower on average compared to the positive IgG group (4.79). Wilcoxon test results of $p>0.05(0.399)$ means that the hypothesis is rejected.

Conclusion: There was no difference between IFNy levels in the positive IgG group and the negative IgG group.

Keywords: Toxoplasmosis, IFNy level, IgG toxoplasmosis.

\section{ABSTRAK}

Latar belakang: Toksoplasma gondii merupakan spesies yang mampu memodulasi sistem imun inangnya. Infeksi T.gondii menyebabkan respon Th1 meningkat untuk memproduksi IFNy, TNFa dan IL-12 yang disekresi oleh sel limfosit T. IFNy diaaktifkan dan menyebabkan meningkatnya produksi Nitric Oxide (NO) yang bisa menyebabkan apoptosis sel dan IFNy bisa memusnahkan T.gondii dengan beberapa mekanisme. Tujuan penelitian ini untuk menentukan kadar IFNy pada pasien IgG positif dan IgG Toksoplasmosis yang asimptomatik.

Metode: Penelitian case control dengan eksperimental laboratorik yang mengunakan darah manusia sebagai objek penelitian. Subjek awalnya di cek darahnya dengan Rapid Test IgG untuk menentukan positif atau negatif infeksi toksoplasma. Kadar IFNY dicek dengan metode ELISA. Untuk menganalisa perbandingan rerata kadar IFNy menggunakan perangkat lunak komputer. Uji normalitas data dengan Saphiro-wilk dan perbandingan kadar IFNy dengan uji Wilcoxon.

Hasil: Kadar IFNy pada kelompok IgG negatif $(4,69)$ rata-rata lebih rendah sedikit dibandingkan dengan kelompok IgG positif $(4,79)$. Uji Wilcoxon hasil p>0,05 $(0,399)$ artinya hipotesis ditolak.

Kesimpulan: Tidak ada perbedaan antara kadar IFNy pada kelompok IgG positif dengan kelompok IgG negatif.

Kata Kunci : Toksoplasmosis, Kadar IFNy, IgG Toksoplasmosis. 


\section{PENDAHULUAN}

Toksoplasmosis adalah adalah penyakit zoonosis yang disebabkan oleh protozoa bersel tunggal yang disebut Toxoplasma gondii (T.gondii) yang biasanya terdapat pada bulu kucing dan hewan peliharaan lainnya. Distribusi penyakit ini tersebar seluruh dunia. Pada penelitian antibodi toksoplasma di Tahiti dan Guatemala, didapatkan infeksi hampir $100 \%$, sedangkan di India hanya $2 \%$. Di Perancis didapatkan kejadian 10 infeksi akut tiap 1000 kehamilan $(0,01 \%)$, sedangkan di Amerika hanya 1,1 tiap 1000 kehamilan. Berdasarkan data dari SDKI (Survei Demografi Kesehatan Indonesia) yang dilakukan pada tahun 2007 , tercatat $35 \%$ ibu hamil mengalami toksoplasma dan pada tahun 2008 kejadian toksoplasma pada ibu hamil meningkat menjadi $47 \%$. Prevalensi toksoplasmosis di Indonesia diduga terus meningkat seiring dengan perubahan pola hidup yang ada pada masyarakat. ${ }^{1.2 .3}$

Toksoplasma gondii merupakan spesies yang mampu memodulasi sistem imun inangnya, pada satu sisi sekelompok T.gondii dapat direspon dan dikendalikan oleh sistem imunnya dengan baik dan di satu sisi yang lain tidak dapat dikendalikan oleh sistem imunnya. Infeksi T.gondii menyebabkan respon Th1 meningkat untuk memproduksi IFNy, TNFa dan IL-12 yang disekresi oleh sel limfosit T. Penelitian eksperimental secara in vivo menunjukkan bahwa sitokin yang paling banyak disekresikan saat infeksi T.gondii adalah IFNy. IFNy dan TNFa menginduksi Reactive Nitrogen Intermediates (RNI) aktivitas microbisidal pada murin makrofaq pada stadium takizoit, RNI mampu menghambat proliferasi limfosit selama fase akut infeksi Tgondii. ${ }^{1,2}$

Pada host yang terinfeksi Toxoplasma memproduksi darah yang tinggi kadar IFNy, hal tersebut terjadi karena parasit pada jaringan tisu yang tipis memproduksi Excretory/Secretory Antigens (ESAs) yang dikeluarkan ke dalam sel tubuh host yang terinfeksi T.gondii. IFNY diaktifkan dan menyebabkan meningkatnya produksi Nitric Oxide (NO) yang bisa menyebabkan Apoptosis sel. ${ }^{2,3,4}$

\section{METODE}

Populasi penelitian Wilayah Kerja Dinas Kesehatan Kota jambi Dari bulan Mei sampai Oktober 2018, dengan sampel 40 kelompok IgG positif Toksoplasmosis dan 40 sampel kelompok lgG negatif toksoplasmosis.

Penelitian ini adalah penelitian Case Control dengan eksperimental laboratorik yang mengunakan darah manusia sebagai objek penelitian. Subjek awalnya di cek darahnya dengan Rapid Test IgG untuk menentukan positif atau negatif infeksi toksoplasma. Kelompok dibagi menjadi dua, yaitu kelompok yang IgG positif dan IgG negatif. Kadar IFNY dicek dengan metode ELISA. 
HASIL

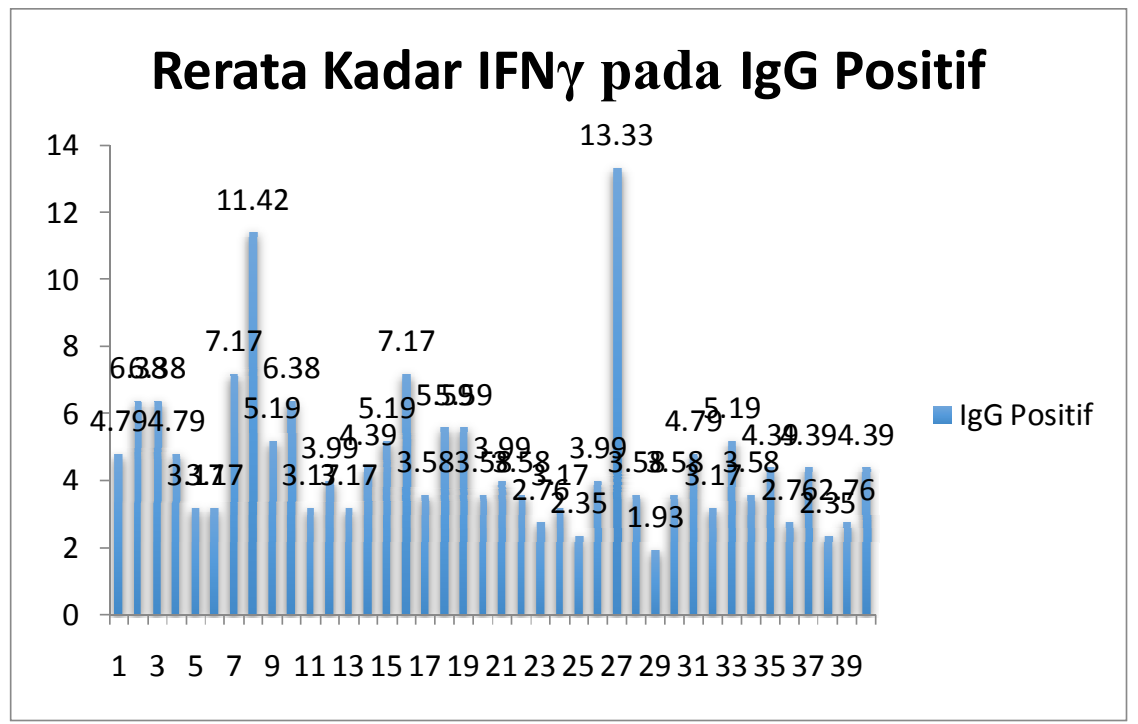

Gambar 1. Rerata Kadar IFNy pada pasien yang IgG positif

Gambar 1 menunjukkan kadar IFNy pada pasien dengan IgG positif didapatkan kadar IFNy paling tinggi yaitu 13,33 dan diikuti dengan 11,42 dan 7,17 dengan kadar terendah 0,63. Rerata kadar IFNy pada kelompok IgG positif 4,79 .

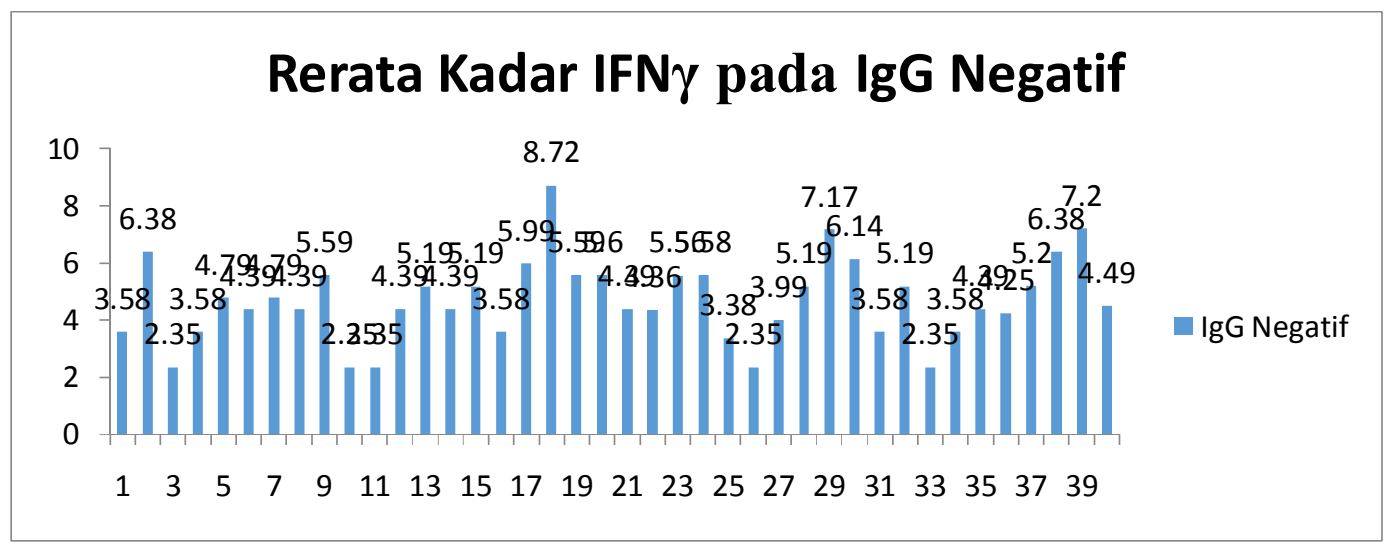

Gambar 2.Rerata Kadar IFNy pada Pasien IgG nya negatif

Gambar 2 menjelaskan bahwa kadar IFNy pada kelompok IgG negatif didapatkan paling tinggi kadar IFNy yaitu 8,72 dan diikuti dengan 7,2 , dengan rerata kadar IFNy pada kelompok negatif adalah
4,69. Pada gambar 1 dan gambar 2 terlihat bahwa kadar IFNY pada kelompok IgG negatif $(4,69)$ rata-rata lebih rendah dibandingkan dengan kelompok IgG positif $(4,79)$. 
Tabel 1. Perbandingan kadar IFNy pada Kelompok yang IgG nya positif dengan IgG negatif.

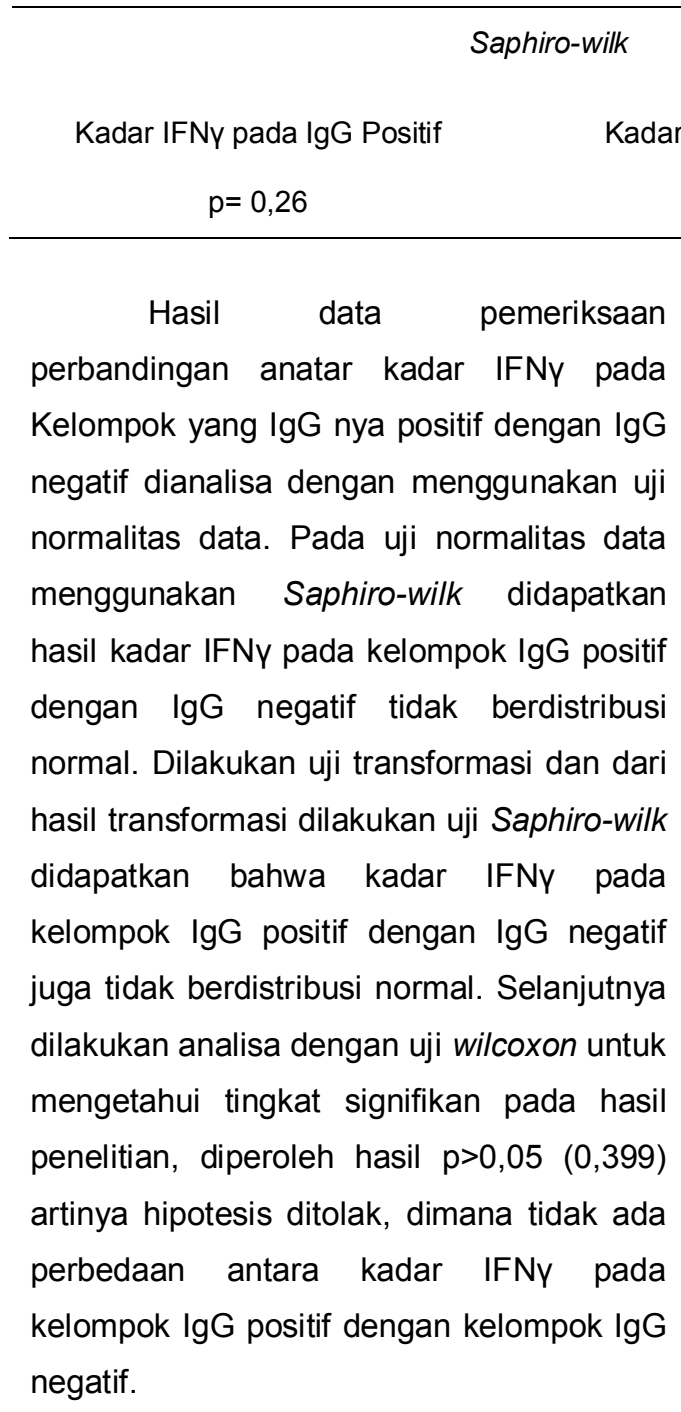

\section{PEMBAHASAN}

Pada awal infeksi, IFN-y diproduksi oleh sel NK. Pada tahap awal infeksi, imunitas terhadap $T$. gondii tergantung pada makrofag dan sel NK. Pada tahap selanjutnya IFN-y diproduksi oleh sel Th (sel T CD4+) dan CTL (CD8+). Terdapat tiga jalur alternatif sintesis IFN- $\gamma$ sebagai respons induk semang terhadap infeksi $T$. gondii. Pertama, infeksi T. gondii pada makrofag merangsang makrofag memproduksi IL-12, TNF-,IL-1, dan IL-15. Sitokin IL-12, bersama-sama dengan IL-1 $\beta$, IL-15 dan TNF- $\alpha$, merangsang sel NK memproduksi IFN-y. Sitokin IFN-y yang dihasilkan sel NK mengaktifkan makrofag TNF- $\alpha$ dan IFN- $\gamma$ bekerja secara sinergis dengan TNF- $\alpha$ menginduksi ekspresi intracellularnitric oxide synthase (iNOS), yang menghasilkan nitric oxide(NO) untuk membunuh T.gondii intraseluler. Jalur kedua, infeksi T. gondii pada makrofag atau APC mendorong sel tersebut memproduksi IL-12. APC mempresentasi peptida parasit melalui MHC II sehingga dikenali oleh sel Th (sel T CD4+). Sel Th yang berikatan dengan MHC II memproduksi IL-2. Sitokin IL-2 dari sel Th dan IL-12 dari APC mendorong diferensiasi dari Th menjadi Th1. Sel Th1 menghasilkan IFN-Y. Jalur ketiga, makrofag atau APC yang terinfeksi mengekspresikan MHC I yang dikenali oleh sel T CTL (sel $\mathrm{T}$ sitotoksik atau sel $\mathrm{T}$ CD8+). Ikatan sel T CTL dengan APC melalui MHC I dan keberadaan IL-2 yang dihasilkan sel Th memicu sel T CTL menghasilkan IFN-y. ${ }^{10,11}$

Pada penelitian ini pada kelompok IgG positif toksoplasma sedikit meningkat dibandingkan dengan kelompok IgG negatif toksoplasma, dan dari analisis data wilcoxon menunjukkan tidak ada perbandingan anatar kelompok IgG positif 
toksoplasma dengan IgG negatif toksoplasma $(p=0,399)$. Hasil penelitian ini menunjukkan bahwa kadar IFNy sedikit meningkat pada kelompok lgG positif toksoplasma, hal tersebut sejalan dengan penelitian Sardjono, dimana kadar IFNy meningkat pada awal infeksi, dan kadar IFNy juga berpengaruh terhadap lamanya infeksi. Kadar IFNY sangat penting dalam pencegahan terjadinya Toxoplasmic Enchepalitis selama infeksi pada infeksi yang cukup lama melalui penghambatan proliferasi takizoit. Penghambatan proliferasi takizoit dengan cara aktivasi makrofag sehingga sel $\mathrm{T}$ memproduksi sel proinnflamasi seperti TNFa, IFNy, untuk menghasilkan NO yang akan memapoptosis sel yang terinfeksi.IFNy dapat menginduksi indoleamine 2,3ddioxygenase (IDO) sehingga menyebabkan peningkatan katabolisme enzim tryptophan dan degradasi tryptophan seluler, menginduksi IDO-1 yang dapat menghambat pertumbuhan parasit pada manusia. $^{5,6,7,8}$

IFNY yang diproduksi dari NK sel dimana meningkat saat terjadinya infeksi, namun pada penelitian ini kadar IFNy pada kelompok IgG positif toksoplasma dengan kelompok IgG negatif toksoplasma yang meningkat tidak signifikan. Faktor yang menyebabkan terjadi hilangnya kemampuan IFNy dalam membunuh parasit dikarenakan hilangnya monosit inflamasi (defisiensi MCP-1, CCR2) yang menghasilkan IFN yang cukup tetapi tidak disertai dengan kemampuan untuk membunuh parasit secara efektif. Penelitian pada mencit juga menunjukan, hilangnya IFN-neutrofil karena defisiensi CXCR2, sehingga dominan TLR11/ TLR12 yang akan menyebabkan kemampuan IFNy dalam mebunuh parasit menurun pada stadium infeksi akut. ${ }^{7,8}$

\section{DAFTAR PUSTAKA}

1. Soedarto. Toksoplasmosis, mencegah dan mengatasi penyakit melindungi ibu dan anak. Jakarta: Sagung Seto; 2012.

2. Subekti DT, Arrasyid NK. Immunopatogenesis Toxoplasma gondii Berdasarkan Perbedaan Galur. Jurnal Veteriner. 2006. 6 (3):128-145.

3. Siregar, Yuniar R. Gambaran Kejadian Toxoplasmosis di Jogyakarta. Buletin Laboratorium Veteriner Balai Besar Veteriner Wates Jogjakarta. 2012. 12 (2).

4. Didik T, Subekti, Arrasyid. Immunopatogenesis Toxoplasma Gondii Berdasarkan Perbedaan Galur. Wartazoa. 2006. 16(3). $128-145$

5. Yin Q, El Ashram S, Liu H, Sun X, Zhao X, Liu X,et al. Interferon Gamma Release Assay : An Effective Tool to Detect Early Toxoplasma gondii Infection in Mice. Plos One. 2015. 17. 1-9.

6. Yuliawati I, Nasronudin. Pathogenesis, Diagnostic and Management of Toxoplasmosis. Indonesian Journal of Tropical and Infection Disesase. 2015. 5(4) : 100-106.

7. Sardjono TW. Kegagalan Kehamilan Akibat Infeksi Toxoplasma gondii Galur RH Dipicu Oleh Overproduksi Interferon Gamma (IFNy). Jurnal Kedokteran Brawijaya. 2005; 21 (3); 133 - 138.

8. Sturge CR, Yarovinsky F. Complex Immune Cell Interplay in the Gamma Interferon Response during Toxoplasma gondii Infection. Journal ASM. 2018; 82 (8); 3090 - 3097. 